\title{
Inmunohistochemical Profile of Solid Cell Nest of Thyroid Gland
}

\author{
María José Ríos Moreno • Hugo Galera-Ruiz • \\ Manuel De Miguel • María Inés Carmona López • \\ Matilde Illanes • Hugo Galera-Davidson
}

Published online: 14 January 2011

(C) The Author(s) 2011. This article is published with open access at Springerlink.com

\begin{abstract}
It is widely held that solid cell nests (SCN) of the thyroid are ultimobranchial body remnants. SCNs are composed of main cells and $\mathrm{C}$ cells. It has been suggested that main cells might be pluripotent cells contributing to the histogenesis of $\mathrm{C}$ cells and follicular cells, as well as to the formation of certain thyroid tumors. The present study sought to analyze the immunohistochemical profile of SCN and to investigate the potential stem cell role of SCN main cells. Tissue sections from ten cases of nodular hyperplasia (non-tumor goiter) with SCNs were retrieved from the files of the Hospital Infanta Luisa (Seville, Spain). Parathormone $(\mathrm{PTH})$, calcitonin $(\mathrm{CT})$, thyroglobulin (TG), thyroid transcription factor (TTF-1), galectin 3 (GAL3), cytokeratin 19 (CK 19), p63, bcl-2, OCT4, and SALL4 expression were evaluated by immunohistochemistry. Patient clinical data
\end{abstract}

M. J. Ríos Moreno • M. De Miguel • M. I. C. López • M. Illanes •

H. Galera-Davidson $(\bowtie)$

Departamento de Citología e Histología Normal y Patológica,

Facultad de Medicina, Universidad de Sevilla,

Avda. Sánchez-Pizjuán s/n,

41009 Seville, Spain

e-mail: hugo@us.es

H. Galera-Ruiz

Departamento de Cirugía. Facultad de Medicina,

Universidad de Sevilla,

Seville, Spain

H. Galera-Ruiz

Servicio de Otorrinolaringología,

Hospital Universitario Virgen Macarena,

Seville, Spain

\section{Illanes}

Servicio de Anatomía Patológica,

Hospital Universitario Virgen Macarena,

Seville, Spain were collected, and tissue sections were stained with hematoxylin-eosin for histological examination. Most cells stained negative for PTH, CT, TG, and TTF-1. Some cells staining positive for TTF-1 and CT required discussion. However, bcl-2, p63, GAL3, and CK 19 protein expression was detected in main cells. OCT4 protein expression was detected in only two cases, and SALL4 expression in none. Positive staining for bcl-2 and p63, and negative staining for PTH, CT, and TG in SCN main cells are both consistent with the widely accepted minimalist definition of stem cells, thus supporting the hypothesis that they may play a stem cell role in the thyroid gland, although further research will be required into stem cell markers. Furthermore, p63 and GAL-3 staining provides a much more sensitive means of detecting SCNs than staining for carcinoembryonic antigen, calcitonin, or other markers; this may help to distinguish SCNs from their mimics.

Keywords Solid cell nests · Main cells · Stem cells · p63 · Galectin-3

\section{Introduction}

Solid cell nests (SCNs) of the thyroid have fascinated pathologists since they were first described by Getzowa [1] in 1907. Although it is now widely accepted that SCNs and so-called "mixed" follicles are indeed ultimobranchial body remnants [2-8], their biological significance remains controversial $[2-4,9,10]$. It has been suggested that these embryonic remnants may be the origin of certain ectopic structures rarely reported in thyroid glands $[3,6]$ and also of certain types of thyroid tumor $[9,10]$. Moreover, SCNs may be a source of confusion in thyroid pathology, as they can mimic a number of pathological disorders $[2,3]$. 
Table 1 Summary of the patient's clinicopathological features and immunostaining findings in solid cell nests

\begin{tabular}{|c|c|c|c|c|c|c|c|c|c|c|c|c|c|c|c|c|c|}
\hline \multirow[t]{2}{*}{ Case } & \multirow[t]{2}{*}{$\mathrm{A} / \mathrm{S}$} & \multirow{2}{*}{$\begin{array}{l}\mathrm{T}_{3}, \mathrm{~T}_{4} \\
\mathrm{TSH}\end{array}$} & \multirow[t]{2}{*}{ PD } & \multicolumn{7}{|c|}{ Main cells } & \multicolumn{7}{|c|}{$\mathrm{C}$ cells } \\
\hline & & & & p63 & bcl-2 & CK19 & GAL-3 & TG & TTF-1* & CT & p63 & bcl-2 & CK19 & GAL-3 & TG & TTF-1 & $\mathrm{CT}$ \\
\hline 1 & $64 / \mathrm{F}$ & WNL & $\mathrm{NH}$ & + & + & + & + & - & - & - & - & - & - & + & - & + & + \\
\hline 2 & $45 / \mathrm{M}$ & WNL & $\mathrm{NH}$ & + & + & + & + & - & - & - & - & - & - & + & - & + & + \\
\hline 3 & $43 / F$ & WNL & $\mathrm{NH}$ & + & + & + & + & - & - & - & - & - & - & + & - & + & + \\
\hline 4 & $36 / \mathrm{F}$ & WNL & $\mathrm{NH}$ & + & + & + & + & - & - & - & - & - & - & + & - & + & + \\
\hline 5 & $70 / \mathrm{F}$ & WNL & $\mathrm{NH}$ & + & + & + & + & - & - & - & - & - & - & + & - & + & + \\
\hline 6 & $37 / \mathrm{F}$ & WNL & $\mathrm{NH}$ & + & + & + & + & - & - & - & - & - & - & + & - & + & + \\
\hline 7 & $44 / \mathrm{M}$ & WNL & $\mathrm{NH}$ & + & + & + & + & - & - & - & - & - & - & + & - & + & + \\
\hline 8 & $69 / \mathrm{F}$ & WNL & $\mathrm{NH}$ & + & + & + & + & - & - & - & - & - & - & + & - & + & + \\
\hline 9 & $62 / \mathrm{F}$ & WNL & $\mathrm{NH}$ & + & + & + & + & - & - & - & - & - & - & + & - & + & + \\
\hline 10 & $46 / \mathrm{F}$ & WNL & $\mathrm{NH}$ & + & + & + & + & - & - & - & - & - & - & + & - & + & + \\
\hline
\end{tabular}

$W N L$ within normal limits, $P D$ pathological diagnosis, $A$ age (years) $/ S$ sex $(F$ female, $M$ male), * $30 \%$ of main cells shown positive immunoreactions, $C K 19$ cytokeratin 19, GAL-3 galectin-3, TTF-1 thyroid transcription factor, $T G$ thyroglobulin, $C T$ calcitonin

Thyroglossal duct cysts, lingual thyroid remnants, and SCNs are believed to harbor pluripotent stem cells $[2,3,7]$. Solid cell nests are composed of two cell types: "main cells" and "C cells" [3]. Main cells, which account for a major proportion of SCNs, are polygonal-to-elongated cells with centrally located, oval nuclei; they have uneven nuclear envelopes and occasionally display strongly eosinophilic cytoplasm with squamoid features (including high molecular weight cytokeratins) but lack intercellular bridges [3]. The minority $\mathrm{C}$ cells are characterized by clear cytoplasm and small, compact, centrally located nuclei [2-4]. In up to $81 \%$ of cases, mixed follicles may be found admixed with bona fide SCNs [2-4]; these are composed of cells resembling main cells and differentiated follicular cells arranged in a follicular lumen-like pattern.

It has been suggested that main cells might be pluripotent cells contributing to the histogenesis of $\mathrm{C}$ cells and follicular cells [10], as well as to some thyroid tumors [11, 12], but little research has addressed this hypothesis. If this were the case, main cells might be expected to display a stem cell phenotype, with the capacity both to self-renew and to generate differentiated progeny, as well as the ability to exist in a mitotically quiescent form, although these properties are not always present in all human tissue stem cells [13].

The present study sought to analyze and characterize thyroid differentiation markers (p63, bcl-2, cytokeratin 19, galectin-3, TTF-1, thyroglobulin, calcitonin) and also stem cell markers (OCT4 and SALL4) in SCNs found in nodular hyperplasia.

\section{Material and Methods}

Formalin-fixed paraffin-embedded tissue sections from ten SCN-containing surgical specimens obtained during total thyroidectomy were retrieved from the files of the Hospital Infanta Luisa (Seville, Spain). Sections were stained with hematoxylin/eosin and evaluated by two pathologists. Patient age, sex, functional status, and underlying SCNassociated thyroid disease are summarized in Table 1. The study was approved by the Hospital Ethical Committee and informed consent was obtained from all participants.

For immunohistochemical analysis, $4 \mu \mathrm{m}$ serial sections were stained with a panel of antibodies (Table 2) using the streptavidin-biotin-peroxidase complex technique. Negative (primary antibody replaced by non-immune mouse serum) and positive controls were included in each slide run. All controls gave satisfactory results. A minimum of $10 \%$ positive staining was adopted as a cut-off for all markers. For p63 and TTF-1, only nuclear staining was considered specific, while for other markers, only cytoplasmic staining was accepted. Staining for GAL-3 was deemed positive when observed in both nucleus and cytoplasm. Positive nuclear and cytoplasmic staining for OCT4 and SALL4 was evaluated.

Table 2 Antibodies used for immunohistochemical analysis

\begin{tabular}{lll}
\hline Antigen & Antibody & Dilution \\
\hline Calcitonin & Polyclonal (BioGenex, San Ramon CA) & $1: 5,000$ \\
TTF-1 & 8G7G3/1 (Dako, Glustrup, Denmark) & $1: 2,000$ \\
Thyroglobulin & DAK-Tg6 (Dako, Glustrup, Denmark) & $1: 2,000$ \\
CK 19 & RCK108 (Dako, Glustrup, Denmark) & $1: 100$ \\
P63 & 4A4 (Dako, Glustrup, Denmark) & $1: 50$ \\
Bcl-2 & 124 (Dako, Glustrup, Denmark) & $1: 20$ \\
Galectin-3 & 9C4 (Dako, Glustrup, Denmark) & $1: 200$ \\
\hline
\end{tabular}

TTF-1 thyroid transcription factor-1, CK 19 cytokeratin 19 


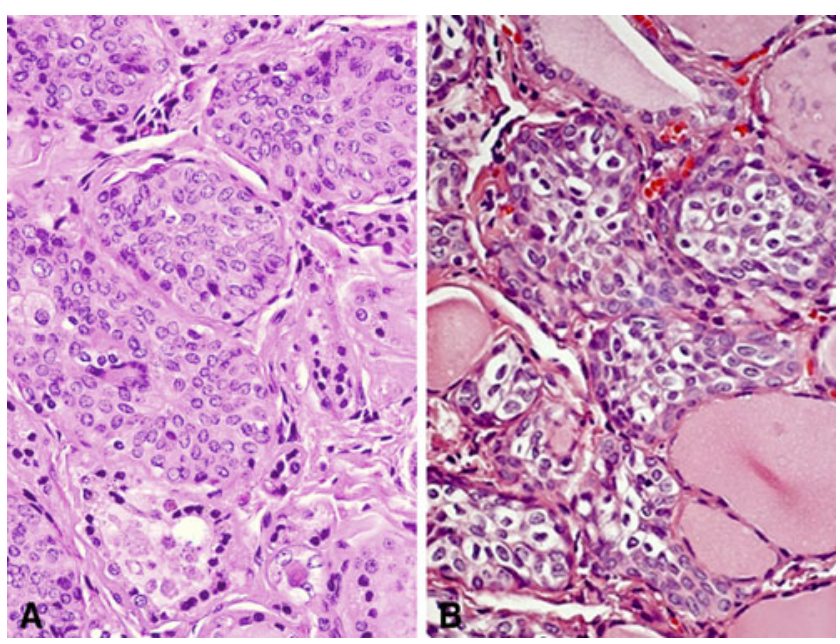

Fig. 1 Solid cell nests of the human thyroid. a. Solid cell nest composed of a complex admixture of main and C-cell (X 20). b. Cystic SCNs. Mixed follicles composed of cells resembling SCN main cells and cuboidal cells arranged in a follicle-like structure $(\mathrm{H} / \mathrm{E}, \times 40)$

\section{Results}

All tissue sections contained SCNs which are composed of a complex admixture of main cells and $\mathrm{C}$ cells, as previously described (Fig. 1a). Main cells displayed frequent nuclear grooving. Intermingled with main cells, and mainly confined to the periphery of cell nests, $\mathrm{C}$ cells were numerically less conspicuous and were characterized by clear or empty cytoplasm and round nuclei. In six cases $(60 \%)$, solid cell nests contained mixed follicles - structures lined by main cells and follicular epithelium with colloid and/or clumps of eosinophilic material in the lumen (Fig. 1b).

Positive staining for P63 was restricted to $\mathrm{SCN}$ main cells (Fig. 2a). On all sections, $\mathrm{C}$ cells stained negative for p63. No positive staining for p63 was observed in adjacent thyroid tissue. Main cells in all tissue sections displayed strong nuclear staining for bcl-2, while staining was negative in C cells (Fig. 2b). Positive staining for CK19 was observed consistently in main cells, as well in follicular cells of mixed and some adjacent follicles (Fig. 2c). In all tissue sections, both main cells and $\mathrm{C}$ cells showed strong nuclear and cytoplasmic staining for GAL-3 (Fig. 2d). No positive staining for GAL-3 was detected in adjacent thyroid tissue.

TG is considered the most specific marker of thyroid follicular differentiation. Here, none of the SCNs stained positive for TG (Fig. 2e). Conversely, thyroid follicular cells and colloid were strongly positive for TG. CT staining was detected in $\mathrm{C}$ cells of all SCNs and in parafollicular cells of adjacent thyroid tissue (Fig. 2g). Positive staining for TTF-1 was detected in all differentiated cells of the thyroid parenchyma and in a few SCN cells, mainly those forming mixed follicles (Fig. 2h). Positive staining for PTH was not detected either in SCNs or in surrounding thyroid tissue (Fig. 2f). Immunohistochemical findings and clinical data are summarized in Table 1.

Only two cases showed granular cytoplasmic staining to be negative in all cases for SALL4.

\section{Discussion}

Solid cell nests may pose a challenge to the thyroid specialist, since they may be confused with squamous metaplasia, metastatic squamous carcinoma, papillary microcarcinoma, medullary carcinoma, and $\mathrm{C}$ cell hyper-
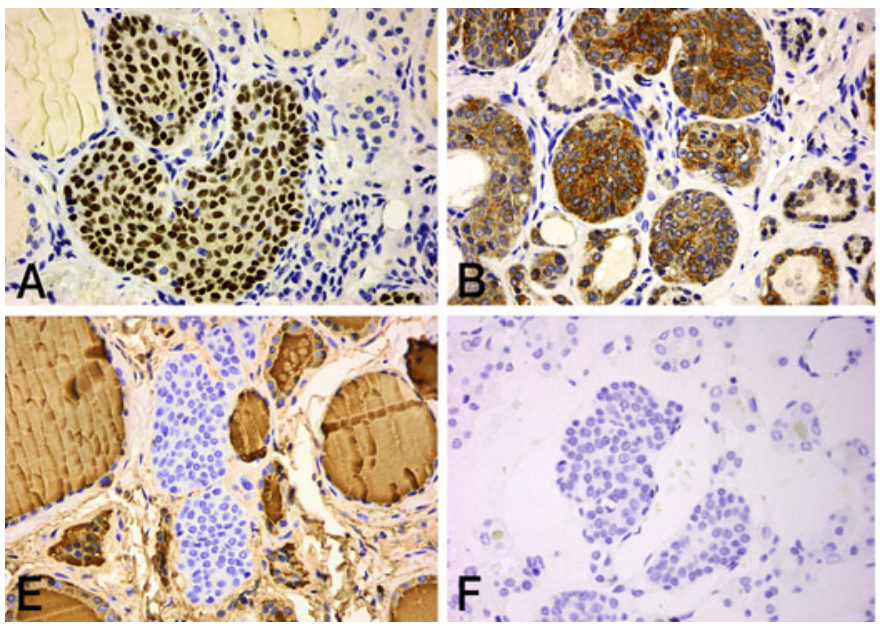

Fig. 2 Immunohistochemical analysis. a. p63, strong nuclear staining in main cells $(\times 40)$. b. bcl-2, strong cytoplasmic staining in main cells $(\times 40)$.c. CK19, moderate cytoplasmic staining in main cells $(\times 40)$. d. GAL-3, strong cytoplasmic, and nuclear staining. Positive staining in
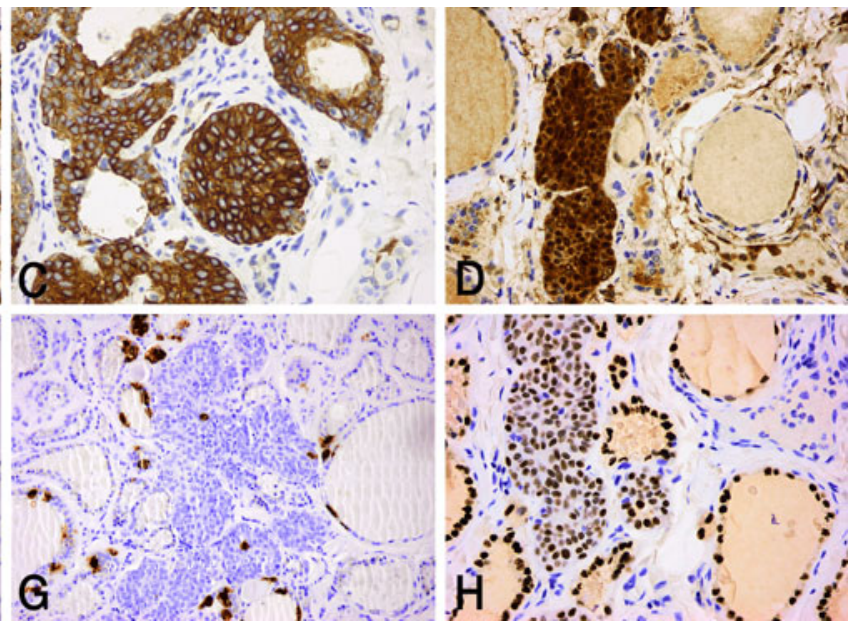

both main and $\mathrm{C}$ cells. e, f TG and PTH, negative staining in both main and $\mathrm{C}$ cells $(\times 40)$. $\mathrm{g}$ CT, moderate cytoplasmic staining in $\mathrm{C}$ cells $(\times 20)$. $\mathbf{h}$ TTF-1, moderate nuclear staining in a small number of $\mathrm{SCN}$ cells, mainly those forming mixed follicles $(\times 40)$ 
plasia $\mathrm{C}[2,3]$. It has been assumed that a histological evaluation based on the "typical" immunohistochemical profile of SCNs (CEA and cytokeratins) should be sufficient to distinguish them from their mimics [2, 3]. However, since CEA and cytokeratins are also coexpressed in some neuroendocrine carcinomas [10, 14], other more specific markers are required.

As reported by other authors [15], expression of GAL-3 in the present study was sufficiently restricted to SCNs. Moreover, positive staining for p63 was detected in SCN main cells but not in surrounding thyroid tissue. Other authors report similar findings $[11,12,16]$, adding that $\mathrm{p} 63$ is not expressed in certain differentiated carcinomas (medullary and follicular) $[12,17]$ and indeed is only exceptionally expressed in foci of squamous metaplasia in papillary carcinomas [18]. Thus, p63 may prove a highly effective marker for distinguishing SCNs from other pathologies.

Although there is no precise definition of stem cells, it is generally understood that they exhibit the capacity both to self-renew and to generate differentiated progeny, as well as the ability to exist in a mitotically quiescent form, although these properties are not always present in all human tissue stem cells [13].

P63 is a structural homolog belonging to the p53 tumor suppressor family involved in the survival and differentiation of stem cells in various epithelia [19, 20]. It has been suggested that p63 may trigger the differentiation of certain specific cell lines [19-21]. In addition, strong bcl-2 expression was detected here in main cells; this is characteristic of a non-committed embryonic phenotype associated with stem cells [22].

Main cells stained negative for two differentiation markers, PTH and TG; this allowed SCNs to be distinguished from parathyroid tissue remnants and suggested the absence of main cell differentiation towards TG-producing follicular cells. However, positive staining for CT was occasionally detected in SCN cells which resembled parafollicular cells in surrounding thyroid tissue, suggesting an intra-SCN differentation of this cell line. Positive staining for TTF-1 was detected in some peripheral SCN cells; to judge by the findings of other authors, these were probably $\mathrm{C}$ cells [21]. Positive TTF-1 staining was also noted in mixed follicle cells and in all follicles in surrounding thyroid tissue. The hypothesis regarding the embryonic nature of SCNs is borne out by the fact that TTF-1 - an early marker of thyroid cell differentiation $[23,24]$ - was not expressed by most SCN cells (undifferentiated cells). The putative stem cell role of $\mathrm{SCNs}$ is further supported by the continuity observed between main cells, mixed follicles, and follicular and parafollicular cells. This strongly suggests that, as reported by other authors, SCN main cells may be pluripotent cells contributing to the histogenesis of $\mathrm{C}$ cells and follicular cells as well as to some thyroid tumors [10]. This hypothesis is borne out by the immunohistochemical profile of SCNs obtained in the present study and by the findings of other authors who report a marked capacity for self-renewal (telomerase activity) a and low proliferation index in these cells [11].

Until now, SCNs have been seen solely as a morphological feature of thyroid tissue; a number of hypotheses have been put forward regarding their nature and their purpose. The results of the present study using stem cell markers failed to confirm the initial hypothesis, since OCT4 protein expression-whose significance is uncertain - was detected in only two cases, and SALL4 expression in none. Future research should thus focus on other specific stem cell markers (e.g., NANOG, SOX2).

As part of the general quest to identify specific stem cell populations in a range of organs and tissues in both healthy and sick patients [25, 26], a number of authors have postulated a stem cell role for SCNs in the thyroid gland [10]; some studies have even linked them to the genesis of several tumors, including papillary, mucoepidermoid, and squamous carcinoma $[10,11,27]$. Attempts have also been made to demonstrate the presence the same BRAF mutation (V600E) in SCNs and in micropapillary carcinoma [16]. There appears to be no evidence to support the link between SCNs and medullary carcinoma posited by a several authors [4, 28].

The literature, accordingly, contains contradictory views on the potential link between stem cells, SCNs ad thyroid carcinoma; however, all these views are based on immunohistochemical profiles which fail to include absolutely specific stem cell markers $[29,30]$. The present results contribute to a better knowledge of the nature of SCNs and may help clarify the genesis of thyroid tumors; however, they provide no indication of potential therapeutic strategies other than surgery, which for the time being remains the only option.

Further research is required to determine the relationship between main cells and certain thyroid carcinomas, particularly papillary thyroid carcinoma, whose cells-like SCN cells-display strong positive staining for CK 19.

Conflicts of Interest The authors have no conflict of interest to declare.

Open Access This article is distributed under the terms of the Creative Commons Attribution Noncommercial License which permits any noncommercial use, distribution, and reproduction in any medium, provided the original author(s) and source are credited.

\section{References}

1. Getzowa S. Ueber die Glandula parathyreoidea, intrathyreoidale Zellhaufen derselben und Reste des postbranchialen köpers. Virchows Arch A Pathol Anat Histopathol 188: 181-234. 1907 
2. Harach HR. Solid cell nests of the thyroid. J Pathol 155:191-200. 1988

3. Cameselle-Teijeiro J, Varela-Durán J, Sambade C, et al. Solid cell nests of the thyroid: light microscopy and immunohistochemical profile. Hum Pathol 25:684-693. 1994

4. Martin V, Martin L, Viennet G, Challier B, Carbillet J, Fellmann D. Solid cell nests and thyroid pathologies. Retrospective study of 1,390 thyroids. Annu Pathol 20: 196-201. 2000

5. Harach HR. Mixed follicles of the human thyroid gland. Acta Anat (Basel) 129: 27-130. 1987

6. Bykov VL. Tissue of ultimobranchial origin in normal and pathologically altered thyroid gland. Arkh Patol 55: 81-84. 1993

7. Beckner ME, Shultz JJ, Richardson T. Solid and cystic ultimobranchial body remmants in the thyroid. Arch Pathol Lab Med 114: 1049-1052. 1990

8. Williams ED, Toyn CE, Harach HR. The ultimobranchial body and congenital thyroid abnormalities in man. J Pathol 159:135-141. 1989

9. Cameselle-Teijeiro J. Mucoepidermoid carcinoma and solid cell nests of the thyroid. Hum Pathol 27:861-863. 1996

10. Cameselle-Teijeiro J, Febles-Perez C, Sobrinho-Simoes M. Papillary and mucoepidermoid carcinoma of the thyroid with anaplastic transformation: a case report with histologic and immunohistochemical findings that support a provocative histogenetic hypothesis. Pathol Res Pract 191:1214-1221. 1995

11. Preto A, Cameselle-Teijeiro J, Moldes-Boullosa J, Soares P, et als. Telomerase expression and profilerative activity suggest a stem cell role for thyroid solid cell nests. Mod Pathol 17:819-826. 2004

12. Reis-Filho J, Preto A, Soares P, et al. p63 expression in solid cell nests of the thyroid: further evidence for a stem cell origin. Mod Pathol 16:43-48. 2003

13. Morrison SJ, Shah NM, Anderson DJ. Regulatory mechanisms in stem cell biology. Cell 88:287-298. 1997

14. Baloch ZW, Solomon AC, LiVolsi VA. Primary mucoepidermoid carcinoma and sclerosing mucoepidermoid carcinoma with eosinophila of the thyroid gland: a report of ine casa. Mod Pathol 13: 802-807. 2000

15. Faggiano A, Talbot M, Baudin E, Bidart JM, Schlumberger, Caillou B. Differential expression of galectin 3 in solid cell nests and C cells of human thyroid. J Clin Pathol 56: 142-143. 2003

16. Cameselle-Teijeiro J, Abdulkader I, Pérez-Becerra R, et al. BRAF mutation in solid cell nest hyperplasia associated with papillary thyroid carcinoma: a precursor lesion?. Human Pathol 40: 741744.2009

17. Di Como CJ, Urist MJ, Babayan I, Drobnjak M, Hedvat CV, Teruya-Feldstein J, et al. p63 expression profiles in human normal and tumor tissues. Clin Cancer Res 8:494-501. 2002
18. Preto A, Reis-Filho JS, Ricardo S, Soares P. p63 expression in papillary and anaplastic carcinomas of the thyroid gland: lack of an oncogenetic role in tumorigenesis and progression. Pathol Res Pract 198:449-54. 2002

19. Barbareschi M, Pecciarini L, Cangi MG, et al. p63, a p53 homologue, is a selective nuclear marker of myoepithelial cells of the human breast. Am J Surg Pathol 25:1054-1060. 2001

20. Mills AA, Zheng B, Wang XJ, et al. p63 is a p53 homologue required for limb and epidermal morphogenesis. Nature 398: 708713. 1999

21. Reis-Filho JS, Torio B, Albergaria A, et al. p63 expression in normal skin and usual cutaneous carcinomas. J Cutan Pathol 29:517-523. 2002

22. Lu QL, Abel P, Foster CS, et al. Bcl-2: role in epithelial differentiation and oncogenesis. Hum Pathol 27:102-110. 1996

23. Reis-Filho JS, Milanezi F, Silva P, Schmitt FC. Maspin expression in myoepithelial tumors of the breast. Pathol Res Pract 197:81721. 2001

24. Reis-Filho JS, Carrilho C, Valenti C, Leitao D, Ribeiro CA, Ribeiro SG, et al. Is TTF1 a good immunohistochemical marker to distinguish primary from metastatic lung adenocarcinomas? Pathol Res Pract 196: 835-40. 2000

25. Hombach-Klonisch S, Panigrahi S, Rashedi I, Seifert A, Alberti E, Pocar P, Kurpisz M, Schulze-Osthoff K, Mackiewicz A, Los M. Adult stem cells and their trans-differentiation potential- perspectives and therapeutic applications. J Mol Med 86:13011314.2008

26. Klonisch T, Wiechec E, Hombach-Klonisch S, Ande SR, Wesselborg S, Schulze-Osthoff K, Los M. Cancer stem cell markers in common cancers - therapeutic implications. Trends Mol Med 14:450-460. 2008

27. Burstein DE, Nagi C, Wang BY, Unger P. Immunohistochemical detection of p53 homolog p63 in solid cell nests, papillary thyroid carcinoma, and Hashimoto's thyroiditis: a stem cell hypothesis of papillary carcinoma oncogenesis. Hum Pathol 35:465-473. 2004

28. Ozaki O, Ito K, Fujisawa T, Kawano M, Iwabuchi H, Kitamura Y, Sugino K, Mimura T. Solid cell nests of the thyroid in medullary thyroid carcinoma. Histopathology. 24(1):77-80.1994

29. Cameselle-Teijeiro J, Preto A, Soares P, Sobrinho-Simões M. A stem cell role for thyroid solid cell nests. Hum Pathol 36(5):590 591. 2005

30. Burstein DE, Unger P, Nagi C, Wang BY. Thinking "out of the nest"-a reply to "a stem-cell role for thyroid solid cell nests [letter]". Hum Pathol 36(5):591-592. 2005 